\title{
Post Traumatic Growth pada Wanita yang Bercerai
}

\section{Post Traumatic Growth in Divorced Women}

\author{
Siti Nur Asiyah ${ }^{1}$, Risna Amalia ${ }^{2}$ \\ ${ }^{1}$ Fakultas Psikologi dan Kesehatan, Universitas Islam Negeri Sunan Ampel Surabaya \\ Nurays72@yahoo.co.id
}

\begin{abstract}
Abstrak
Sebuah fenomena yang terjadi di masyarakat, tidak banyak wanita yang telah bercerai mempunyai kekuatan untuk menghadapi kehidupan setelah masa perceraian termasuk dalam menjalani kehidupan sosialnya. Namun tidak sedikit pula wanita yang berhasil bangkit dari pengalaman masa krisisnya dan menjadi pelajaran yang berharga untuk kehidupan selanjutnya Penelitian ini bertujuan untuk menggambarkan post traumatic growth menuju perubahan yang positif pada wanita pasca perceraian. Selanjutnya, faktor-faktor yang mempengaruhi post traumatic growth menuju perubahan hidup yang positif pada individu setelah perceraian. Partisipan pada penelitian ini terdapat 3 subjek yakni dengan karakteristik jenis kelamin perempuan, telah bercerai, usia dewasa awal (20-30 tahun) dan telah mengalami post traumatic growth. Metode yang digunakan dalam penelitian ini adalah metode penelitian kualitatif yang berlandaskan fenomenologi. Hasil penelitian menunjukkan terdapat beberapa hal yang menunjang gambaran post traumatic growth dan faktor-faktor yang mempengaruhi post traumatic growth yang meliputi pengolahan emosi yang baik serta menumbuhkan motivasi dalam diri akan kemungkinan-kemungkinan baru. Kemudian terdapat dua faktor utama yang mempengaruhi aspek post traumatic growth pada wanita yang bercerai. Faktor eksternal adalah dorongan dan motivasi kedua orang tua serta dukungan dari teman-teman terdekat sehingga memicu penguatan faktor internal yang meliputi, faktor peningkatan spiritualitas, kekuatan dalam diri dan relasi sosial semakin baik.
\end{abstract}

Kata kunci: Wanita Dewasa Awal, Post Traumatic Growth, Bercerai

\begin{abstract}
A phenomenon that occurs in society, not many divorced women have the power to face life after divorce, including in living their social life. But not a few women who managed to rise from the experience of the crisis and become valuable lessons for the next life. This study is to describe post traumatic growth toward positive change in women who are divorced. Furthermore, the factors that influence post traumatic growth lead to a positive life change in the women who are divorced. Participants in this study there are 3 subjects with female sex characteristics, have divorced, early adulthood (20-30 years) and have experienced post traumatic growth. The method used in this study is qualitative research method based on phenomenology. The result of the study indicate that there are several things that support to descripe post traumatic growth and the factors that influence post traumatic growth which includes positive emotional processing as well as motivation in the self of new possibilities. Then there are two main factors that affect the post traumatic growth aspect in women who are divorced. The external factors is the encouragement and motivation of both parents and support from friends closest to trigger the strengthening of internal factors that include, factors of increasing spirituality, inner strength and social relations the better.
\end{abstract}

Keywords: Adult Women Early, Post Traumatic Growth, Divorce

\section{Pendahuluan}

Pernikahan merupakan perpaduan insingtif manusiawi antara laki-laki dan perempuan dimana bukan sekedar memenuhi kebutuhan jasmani (menghalalkan hubungan kelamin antara laki-laki dan 
perempuan) tetapi dalam rangka mewujudkan kebahagiaan berkeluarga yang diliputi dengan rasa ketentraman serta kasih sayang dengan cara yang diridhoi oleh Allah SWT. Kehidupan berkeluarga tidak selalu harmonis seperti yang diangankan, karena memelihara kelestarian dan keseimbangan hidup bersama suami istri bukanlah perkara yang mudah dilaksanakan. Perlu disadari bahwa banyak pernikahan yang tidak membuahkan tetapi tidak diakhiri dengan perceraian karena perkawinan tersebut didasari oleh pertimbangan agama, moral, kondisi ekonomi dan kondisi lainnya. Tetapi banyak juga perkawinan yang diakhiri dengan cara perpisahan dan pembatalan, baik secara hukum maupun diam-diam (suami/istri) meninggalkan (dalam Hotmauli, 2008).

Indonesia merupakan salah satu negara dengan tingkat perceraian yang cukup tinggi. Hal ini terbukti dengan data-data yang tercatat di Pengadilan Agama dan Pengadilan Negeri. Hal ini juga dapat dibuktikan bila mengunjungi Pengadilan Agama selalu ramai dengan orang-orang yang menunggu sidang cerai. Data-data perceraian berikut dihimpun dari beberapa media secara historis, angka perceraian di Indonesia bersifat fluktuatif. Hal itu dapat ditilik dari hasil penelitian Mark Cammack, guru besar dari Southwestern School of Law-Los Angeles, USA. Berdasarkan temuan Mark Cammack, pada tahun 1950-an angka perceraian di Asia Tenggara, termasuk Indonesia, tergolong yang paling tinggi di dunia. Pada dekade itu, dari 100 perkawinan, 50 di antaranya berakhir dengan perceraian.

Perceraian menjadi permasalahan yang setiap tahunnya memperlihatkan peningkatan yang signifikan. Angka gugat cerai di Indonesia terus meningkat sepanjang tahun. Kondisi ini merata hampir di semua daerah di Indonesia. Angka perceraian yang terjadi di Indonesia. Berdasarkan data dari Badan Pusat Statistik, pada kasus perceraian tahun 2012 yakni, cerai dan talak sebanyak 346.480 kasus. Di tahun 2013, cerai dan talak sebanyak 324.247 kasus. Di tahun 2014, cerai dan talak sebanyak 344.237 kasus. Di tahun 2015, cerai dan talak sebanyak 347.256 kasus (Badan Pusat Statistik, 2017).

Jawa Timur merupakan provinsi kedua dengan angka perceraian paling tinggi di Indonesia setelah Jawa Barat. Dalam kurun waktu tahun 2012 sampai 2015, di Jawa Timur terdapat 353.488 kasus perceraian. Berdasarkan data dari Badan Pusat Statistik, pada kasus perceraian di Jawa Timur tahun 2012 yakni, cerai dan talak sebanyak 91.449 kasus. Di tahun 2013, cerai dan talak sebanyak 85.484 kasus. Di tahun 2014, cerai dan talak sebanyak 89.406 kasus. Di tahun 2015, cerai dan talak sebanyak 87.149 kasus (Badan Pusat Statistik, 2017).

Di Gresik angka perceraian selalu meningkat dalam kurun waktu tahun 2012 sampai 2015, di Gresik terdapat 7.869 kasus perceraian. Berdasarkan data dari Pengadilan Agama Gresik, terdapat 1.885 kasus perceraian di Gresik pada tahun 2012 yakni, cerai talak sebanyak 622 kasus dan cerai gugat sebanyak 1.263 kasus. Di tahun 2013 terdapat 1.918 kasus perceraian, dengan rincian cerai talak sebanyak 645 kasus dan cerai gugat sebanyak 1.273 kasus. Di tahun 2014 terdapat 2.002 kasus perceraian, dengan rincian cerai talak sebanyak 639 kasus dan cerai gugat sebanyak 1.363 kasus. Di tahun 2015 terdapat 2.064 kasus perceraian, dengan rincian cerai talak sebanyak 655 kasus dan cerai gugat sebanyak 1.409 kasus (Pengadilan Agama Gresik, 2017).

Faktor utama terjadinya perceraian dalam kehidupan perkawinan yang telah terbangun yaitu ketidakmampuan suami dan istri mengatasi permasalahan dalam perkawinan tersebut. Hurlock (1980) menjelaskan ketidakmampuan seseorang yang telah dewasa (suami dan istri) dalam mengatasi permasalahan perkawinan menjadikan mereka cenderung cemas, kecewa dan tidak bahagia, namun bagi mereka yang mampu mengatasinya menjadi pribadi yang teguh, mantap dan tenteram.

Perceraian bukanlah hal yang mudah untuk dilalui bagi individu yang mengalaminya. Hurlock (1980), mengemukakan bahwa efek traumatik yang ditimbulkan akibat perceraian biasanya lebih besar dari pada efek kematian, karena sebelum dan sesudah perceraian sudah timbul rasa sakit dan tekanan emosional, serta mengakibatkan celah sosial. Oleh karena itu dukungan sosial dari keluarga, kerabat dan teman sangat dibutuhkan dan kehadiran dukungan sosial itu akan sangat membantu individu yang bercerai dan mengurangi dampak negatif perceraian terhadap dampak kesejahteraan psikologis. Kemampuan seseorang menghadapi situasi pasca perceraian akan berbeda pada setiap individu. Beberapa wanita yang sedang dalam masa transisi khususnya pada dewasa awal yang mengalami perceraian akan merasa terpuruk, rendah diri dan mengalami ketakutan yang luar biasa dalam menghadapi kehidupan sosialnya. Namun beberapa wanita pada usia dewasa awal juga mengalami hasil positif setelah mengalami perceraian yang mana hal ini disebut post traumatic growth. 
Post traumatic growth menurut Tedeschi dan Calhoun (2006) adalah suatu perubahan positif seseorang menuju level yang lebih tinggi setelah mengalami peristiwa traumatis. Post traumatic growth bukan hanya kembali ke sediakala, tapi juga mengalami peningkatan psikologis yang bagi sebagian orang adalah sangat mendalam. Peningkatan tersebut terlihat dari tiga dimensi yang berkembang, yaitu perubahan persepsi diri, hubungan dengan orang lain dan perubahan falsafah hidup. Post traumatic growth ini merupakan hasil dari perjuangan hidup yang menantang.

Sebuah fenomena yang terjadi di masyarakat, tidak banyak wanita yang telah bercerai mempunyai kekuatan untuk menghadapi kehidupan setelah masa perceraian termasuk dalam menjalani kehidupan sosialnya. Namun tidak sedikit pula wanita yang berhasil bangkit dari pengalaman masa krisisnya dan menjadi pelajaran yang berharga untuk kehidupan selanjutnya. Secara umum dan logika kaum pria lebih banyak menderita kecemasan dan rasa takut menghadapi masa depan setelah perceraian, mengingat fungsinya sebagai penanggung jawab atas diri dan keluarganya, serta sebagai pilar utama untuk membahagiakan rumah tangga. Akan tetapi pada kenyataannya setelah melalui penelitian dan studi ilmiah, terbukti bahwa wanitalah yang lebih sering merasakan kecemasan dan ketakutan dalam menghadapi kehidupan pasca bercerai. Melihat hal ini peneliti tertarik untuk memilih wanita khususnya pada usia dewasa awal sebagai subjek penelitian karena berdasarkan penelitian dan study yang pernah dilakukan menunjukkan bahwa wanita lebih perasa dan pada tingkat tertentu, mereka lebih sering terpengaruh dengan kesulitan dalam menghadapi kehidupan sosialnya karena pada umumnya masyarakat masih berpandangan negatif terhadap perceraian, sehingga hal ini dapat menimbulkan rasa malu dan keputus asaan pada wanita. Penelitian ini bertujuan untuk menggambarkan post traumatic growth pada wanita yang bercerai serta menggambarkan faktor-faktor yang mempengaruhi terbentuknya post traumatic growth menuju perubahan hidup yang positif pada wanita setelah perceraian.

\section{Metode Penelitian}

Metode penelitian yang digunakan dalam penelitian ini adalah kualitatif dengan menggunakan paradigma fenomenologi. Alasan penelitian ini menggunakan metode kualitatif karena penelitian ini bertujuan untuk mengungkap gejala secara holistic kontekstual melalui pengumpulan data latar alami dengan memanfaatkan diri peneliti sebagai instrumen kunci.

Pertimbangan dalam pemilihan informan ini adalah seseorang yang pernah mengalami perceraian, usia dewasa awal (20-30 tahun), ada rasa trauma akan perceraian sehingga mengancam kehidupannya dan telah mengalami post traumatic growth. Informan penelitian ini adalah tiga orang wanita dewasa awal yang sama-sama berstatus janda dan berusia $<30$ tahun. Peneliti memilih informan yang berusia 20-30 tahun karena seseorang yang berumur 20-an (sebelum 30-an), kondisi emosionalnya tidak terkendali. Individu cenderung labil, resah dan mudah memberontak. Pada masa ini juga emosi seseorang sangat bergelora dan mudah tegang. Hal ini dikarenakan seseorang harus mengadakan penyesuaian dengan peran barunya (pernikahan vs pekerjaan). Jika individu tidak dapat mengatasinya, maka akan menimbulkan masalah.

Data diperoleh melalui wawancara dan observasi dengan subjek dan significant other. Wawancara dan observasi yang digunakan menggunakan pedoman umum. Prosedur analisis dan interpretasi data pada penelitian ini menggunakan analisis data lapangan model Miles dan Huberman. Miles dan Huberman (dalam Sugiyono, 2010) mengemukakan bahwa aktivitas dalam analisis data kualitatif dilakukan secara interaktif dan berlangsung secara terus menerus sampai tuntas, sehingga datanya sudah jenuh. Aktivitas dalam analisis data yaitu reduksi data, display data dan kesimpulan atau verifikasi.

\section{Hasil Penelitian}

Ada perubahan positif pada diri individu menuju level yang lebih tinggi setelah mengalami peristiwa traumatik dari peristiwa hidup yang penuh perjuangan dan menantang disebut dengan Post Traumatic Growth. Individu yang mengalami Post Traumatic Growth menunjukkan perubahan yang meningkat pada persepsi diri, hubungan dengan orang lain dan falsafah hidup.

Subjek 1 dapat menyadari bahwa ia lebih memiliki kekuatan dan kemampuan untuk menghadapi suatu tantangan dibanding sebelumnya. Dalam perubahan persepsi diri, salah satunya 
yakni cara subjek 2 memandang diri sendiri dengan mengikhlaskan semua yang telah diperbuat oleh mantan suaminya dan membuang jauh-jauh perasaan dendam kepadanya, sedangkan subjek 3 memandang diri sendiri dengan merasakan bahwa dirinya sekarang lebih bahagia.

Hubungan subjek 1 dan 2 dengan orang lain pada saat setelah bercerai semakin baik. Subjek 2 semakin mempunyai banyak teman, demikian pula dengan subyek 3. Semua Subjek yakin bahwa mereka lebih beruntung dari orang lain dan lebih bijaksana dari sebelumnya, karena semua subjek merasa telah mampu melewati masa-masa krisisnya

Faktor - faktor yang mempengaruhi Post Traumatic Growth :

1. Penghargaan terhadap hidup

Pada diri subjek 1 ada perubahan terutama mengenai prioritas hidup, dimana subyek 1 memilih untuk lebih fokus pada kuliah yang sedang ditempuhnya, sedangkansubjek 2 lebih memprioritaskan hidupnya pada pikiran positif untuk masa depan. Demikian pula dengan subjek 3 yang lebih menekankan prioritas hidup untuk berpikir positif terhadap masa depan dan mengikhlaskan semua masalah yang pernah terjadi dalam hidupnya.

2. Hubungan dengan orang lain

Subjek 1 mampu bangkit dari permasalahan yang dialaminya, salah satunya yakni subjek 1 lebih terbuka pada orang lain. Subjek 2 dapat menjalin hubungan yang lebih baik dengan orang pasca perceraiannya, sehingga dia mempunyai banyak teman, demikian pula dengan subyek 3 .

3. Kekuatan dalam diri

Subjek 1 mempunyai kekuatan dalam diri serta keyakinan bahwa mampu melewati masamasa krisis tersebut. Subjek 2 mempunyai kekuatan dalam diri serta keyakinan bahwa ia mampu melewati masa-masa krisis tersebut, demikian pula dengan subyek 3.

4. Kemungkinan-kemungkinan baru

Semua subjek menginginkan kehidupan baru yang lebih baik pasca perceraiannya dan menjadikan pengalaman perceraian menjadi pelajaran hidup bagi mereka.

5. Perkembangan spiritual

Baik subjek 1 maupun subjek 2 dan subjek 3 mengalami perubahan perkembangan spiritualitas antara sebelum dan setelah bercerai. Mereka semakin banyak mendekatkan diri kepada Alloh dan menjadikan proses perceraian sebagai lahan untuk memaknai diri.

\section{Pembahasan}

\section{Gambaran Post Traumatic Growth}

Subjek 1 dapat menyadari bahwa ia lebih memiliki kekuatan dan kemampuan untuk menghadapi suatu tantangan dibanding sebelumnya. Dalam perubahan persepsi diri, salah satunya yakni cara subjek 2 memandang diri sendiri dengan mengikhlaskan semua yang telah diperbuat oleh mantan suaminya dan membuang jauh-jauh perasaan dendam kepadanya. Sedangkan subjek 3 memandang diri sendiri dengan merasakan bahwa dirinya sekarang lebih bahagia. Menurut Tedeschi \& Calhoun (2006) individu yang mengalami perubahan persepsi dapat menyadari bahwa ia lebih memiliki kekuatan dan kemampuan untuk menghadapi suatu tantangan dibanding sebelumnya. Perubahan persepsi telah dialami oleh ketiga subjek. Meskipun awalnya masih tertutup, namun ketiga subjek mengalami perubahan persepsi.

Hubungan subjek 1 dan 2 dengan orang lain pada saat setelah bercerai semakin baik. Subjek 2 semakin mempunyai banyak teman, demikian pula dengan subyek 3. Semua Subjek yakin bahwa mereka lebih beruntung dari orang lain dan lebih bijaksana dari sebelumnya, karena semua subjek merasa telah mampu melewati masa-masa krisisnya. Menurut Tedeschi \& Calhoun (2006), individu yang mengalami Post Traumatic Growth dapat mencapai rasa yang lebih besar dalam keintiman, kedekatan dan kebebasan untuk menjadi diri sendiri dan dapat mengungkapkan hal-hal yang bahkan tidak diinginkan secara sosial dari diri sendiri. Individu akan dapat meningkatkan relasi dengan orang lain dan tumbuhnya rasa kasih sayang pada orang yang membutuhkan sebagai bentuk empatinya.

Menurut Tedeschi \& Calhoun (2006), perubahan filosofi kehidupan dapat digolongkan menjadi faktor tumbuhnya Post Traumatic Growth. Individu dengan Post Traumatic Growth akan memandang hal-hal kecil dan sederhana menjadi hal yang luar biasa. Ada refleksi dalam diri individu yang lebih dalam seperti kematian, spiritualitas, arti dan tujuan hidup, memahami apa yang penting dalam hidup dan berpeluang mengubah prioritas, seperti dengan siapa mereka menjalani hari dalam hidup, penting 
atau tidaknya kesehatan, kehidupan, penampilan fisik dan hal-hal duniawi, misalnya mobil, rumah dan uang.

Faktor-faktor yang mempengaruhi Post Traumatic Growth :

Pada diri subjek 1 ada perubahan terutama mengenai prioritas hidup, dimana subyek 1 memilih untuk lebih fokus pada kuliah yang sedang ditempuhnya, sedangkansubjek 2 lebih memprioritaskan hidupnya pada pikiran positif untuk masa depan. Demikian pula dengan subjek 3 yang lebih menekankan prioritas hidup untuk berpikir positif terhadap masa depan dan mengikhlaskan semua masalah yang pernah terjadi dalam hidupnya. Penghargaan terhadap hidup merupakan perubahan mengenai hal apa yang penting dalam kehidupan seseorang. Perubahan yang mendasar adalah perubahan mengenai prioritas hidup seseorang yang juga dapat meningkatkan penghargaan kepada hal-hal yang dimilikinya misalnya menghargai kehidupannya.

Subjek 1 mampu bangkit dari permasalahan yang dialaminya, salah satunya yakni subjek 1 lebih terbuka pada orang lain. Subjek 2 dapat menjalin hubungan yang lebih baik dengan orang pasca perceraiannya, sehingga dia mempunyai banyak teman, demikian pula dengan subyek 3 . Hubungan dengan orang lain merupakan perubahan seperti hubungan yang lebih dekat dengan orang lain, lebih intim dan lebih berarti. Seseorang mungkin akan memperbaiki hubungan dengan keluarga atau temannya.

Subjek 1 mempunyai kekuatan dalam diri serta keyakinan bahwa mampu melewati masa-masa krisis tersebut. Subjek 2 mempunyai kekuatan dalam diri serta keyakinan bahwa ia mampu melewati masa-masa krisis tersebut, demikian pula dengan subyek 3. Kekuatan dalam diri merupakan perubahan yang berupa peningkatan kekuatan personal atau mengenal kekuatan dalam diri yang dimilikinya. Semua subjek menginginkan kehidupan baru yang lebih baik pasca perceraiannya dan menjadikan pengalaman perceraian menjadi pelajaran hidup bagi mereka.

Kemungkinan-kemungkinan baru merupakan identifikasi baru individu mengenai kemungkinan baru dalam kehidupan atau kemungkinan untuk mengambil pola yang baru dan berbeda. Yang ditampakkan oleh ketiga subjek adalah mengejar cita-cita dan harapan pendamping masa depan yang lebih baik. Baik subjek 1 maupun subjek 2 dan subjek 3 mengalami perubahan perkembangan spiritualitas antara sebelum dan setelah bercerai. Mereka semakin banyak mendekatkan diri kepada Alloh dan menjadikan proses perceraian sebagai lahan untuk memaknai diri.

Perkembangan spiritualitas merupakan perubahan berupa perkembangan pada aspek spiritualitas dan hal-hal yang bersifat eksistensial. Individual yang tidak religious atau tidak memiliki pengalaman beragama yang baik juga dapat mengalami Post Traumatic Growth. Mereka dapat mengalami pertempuran yang hebat dengan pertanyaan-pertanyaan eksistensial yang mendasar atau pertempuran tersebut mungkin dijadikan sebagai pengalaman Post Traumatic Growth.

\section{Kesimpulan}

1. Gambaran post traumatic growth yakni menyadari bahwa ketiga subjek lebih memiliki kekuatan dan kemampuan untuk menghadapi suatu tantangan dibanding sebelumnya. Dapat meningkatkan relasi dengan orang lain dan tumbuhnya rasa kasih sayang pada orang yang membutuhkan sebagai bentuk empatinya. Serta dapat memahami apa yang penting dalam kehidupan dan berpeluang mengubah prioritas menjadi lebih baik.

2. Sedangkan berdasarkan hasil penelitian, ditemukan lima faktor yang mempengaruhi aspek post traumatic growth yakni penghargaan terhadap hidup, hubungan dengan orang lain, kekuatan dalam diri, kemungkinan-kemungkinan baru dan perkembangan spiritualitas.

\section{Daftar Pustaka}

Ahsyari. 2015. Kelelahan Emosional dan Strategi Coping pada Wanita Single Parent. Jurnal Psikologi. Vol 3, 1, 422-432.

Antasari. 2011. Peran Dukungan Sosial terhadap Pertumbuhan Pasca Trauma: Studi Meta-Analisis. Jurnal Psikologi. Vol 6 No 1.

Dariyo, A. 2003. Psokologi Perkembangan Dewasa Muda. Jakarta: PT Gramedia Widiasarana Indonesia. 
Dekel, S., Ein-Dor, T \& Solomon, Z. 2012. Post Traumatic Growth and Post Traumatic Distress: A Longitudinal Study. Psychological Trauma: Theory, Research, Practice and Policy. Vol 4, 1, 94-101.

Desmita. 2013. Psikologi Perkembangan. Bandung: PT Remaja Rosdakarya.

Haditono, S.R. 2006. Psikologi Perkembangan Pengantar dalam Berbagai Bagiannya. Yogyakarta: Gajah Mada Univaersity Press.

Hagenaars, M.I.A \& Agnes, V.M. 2010. Post Traumatic Growth in Exprosure Therapy for PTSD. Journal of Traumatic Stess. Vol 23, 4, 504-508.

Hamka. 2017. Falsafah Hidup Memecahkan Rahasia Kehidupan Berdasarkan Tuntunan Al-Qur'an dan As-Sunnah. Jakarta: Replubika Penerbit.

Hotmauli. 2008. Kecemasan Pasca Bercerai pada Wanita Dewasa Awal. Jurnal Psikologi.

Hurlock, E.B. 1980. Psikologi Perkembangan: Suatu Pendekatan Sepanjang Rentang Kehidupan. Jakarta: Erlangga.

Istiqomah. 2015. Post Traumatic Growth pada Penderita Kanker Payudara Pasca Mastektomi. Skripsi Psikologi.

Jahja, Y. 2011. Psikologi Perkembangan. Jakarta: Kencana Prenada Media Group.

Jhoseph, S. 2009. Growth Following Adversity: Positive Psychological Perspectives on Post Traumatic Stress. Journal of Psychological Topics. Vol 18, 2. 335-344.

Kartika. 2014. Resiliensi pada Single Mother Pasca Perceraian. Jurnal Psikologi.

Kunst, Winkel \& Bogaerts. 2010. Post Traumatic Growth Moderates the Associaton between Violent Revictimization and Persisting PTSD Symptoms in Victims of Interpersonal Violence: A Six-Month Follow-Up Study. Journal of Social and Clinical Psychology. Vol 29, No 5, 2010, pp. 527-545.

Mahleda \& Hartini. 2012. Post Traumatic Growth pada Pasien Kanker Payudara Pasca Mastektomi Usia Dewasa Madya. Jurnal Psikologi Klinis dan Kesehatan Mental. Vol 1 No 2.

Muslimah. 2012. Konsep Diri pada Janda Cerai (Studi Kasus pada Wanita yang Menjadi Orang Tua Tunggal). Skripsi Psikologi.

Papilia, D.E. dkk. 2008. Human Development (Psikologi Perkembangan). Jakarta: Kencana.

Poerwandari, E.K. 2005. Pendekatan Kualitatif untuk Penelitian Perilaku Manusia. Jakarta: LPSP3 UI.

Rachmawati \& Halimah. 2015. Studi Deskriptif Mengenai Gambaran Post Traumatic Growth (PTG) pada Wanita Penderita Kanker Payudara Pasca Mastektomi di Bandung Cancer Sosiety (Bcs). Prosiding Psikologi. ISSN: 2460-6448.

Rahma \& Widuri. 2011. Post Traumatic Growth pada Penderita Kanker Payudara. Humanitas. Vol VIII No 2.

Retnowati. 2010. Kecemasan pada Wanita Dewasa Muda Setelah Mengalami Perceraian. Jurnal Psikologi.

Santrock, J.W. 1995. Life Span Development (Perkembangan Masa Hidup) jilid 2). Jakarta: Penerbit Erlangga.

Sarafino, E.P. 2014. Health Psychology: Biopsychosocial Interaction $8^{\text {th. }}$ United States: John Wiley \& Sons, Inc. 
Sasongko, R.D., dkk. 2011. Resiliensi pada Wanita Usia Dewasa Awal Pasca Perceraian di Senandung Mulyo. Jurnal Psikologi.

Shafira, F. 2011. Faktor-faktor yang Mempengaruhi Post Traumatic Growth pada Recovering Addict di Unit Pelaksanaan Teknis (UPT) Terapi dan Rehabilitasi BNN Lido. Skripsi Psikologi.

Snyder, C.R \& Lopez, S.J. 2009. Handbook of Positive Psychology. New York: Oxford University Press.

Sugiyono. 2010. Metode Penelitian Kuantitatif, Kualitatif dan R\&D. Bandung: ALFABETA, cv.

Sukirna. 2014. Post Traumatic Growth pada Anak-anak yang Mengalami Peristiwa Traumatik: Eksplorasi Peran Perubahan Keyakinan Dasar, Pikiran Ruminatif dan Dukungan Sosial. Jurnal Psikologi Indonesia. Vol XI No 1, 14-27.

Tedeschi, R.G \& Calhoun, L.G. 2006. Handbook of Post Traumatic Growth Research and Practice. London: Lawrence Erlbaum Associates, Inc.

Tedeschi, R.G \& Calhoun, L.G. 2013. Post Traumatic Growth in Clinical Practice. New York: Routledge Taylor \& Fracis, LLC.

Werdel, M.B \& Wicks, R.J. 2012. Primer on Post Traumatic Growth: An Introduction and Guide. Canada: John Wiley \& Sons, Inc.

https://www.bps.go.id/linkTableDinamis/view/id/893 (Diakses pada tanggal 3 Mei 2017). 